\title{
Labyrinthe
}

14 | 2003

Constructions de la raison

\section{La critique littéraire en ligne}

\section{Laurence Marie}

\section{OpenEdition}

Journals

Édition électronique

URL : http://journals.openedition.org/labyrinthe/605

DOI : $10.4000 /$ labyrinthe.605

ISSN : 1950-6031

Éditeur

Hermann

Édition imprimée

Date de publication : 1 mai 2003

Pagination : 103-105

Référence électronique

Laurence Marie, «La critique littéraire en ligne », Labyrinthe [En ligne], 14 | 2003, mis en ligne le 11 avril 2005, consulté le 06 mai 2019. URL : http://journals.openedition.org/labyrinthe/605 ; DOI : 10.4000/ labyrinthe.605

Ce document a été généré automatiquement le 6 mai 2019.

Propriété intellectuelle 


\title{
La critique littéraire en ligne
}

\author{
Laurence Marie
}

